\title{
Apresentação da seção temática
}

Este número da Revista FAROL reúne em sua Seção Temática oito artigos selecionados a partir da convocatória lançada com o título Estudos Interartes: mediações entre sistemas naturais e

culturais. Os textos tratam do campo ampliado em que se desdobram relações poéticas e estéticas intrínsecas à cooperação entre diversos arranjos de complexidades por meio de máquinas algorítmicas. No conjunto, os autores trazem reflexões sobre aspectos práticos e teóricos da ampla conectividade e do hibridismo de fenômenos integrados sob o impulso do paradigma informacional e da digitalização.

A produção de obras de arte baseadas em funções biológicas e bioquímicas é abordada por Artur Cabral Reis e Suzete Venturelli, em reflexão sobre processos criativos que envolvem máquinas computacionais e plantas. Em perspectiva ligada à ciência molecular, Clarissa Ribeiro propõe a exploração de noções cibernéticas em obra estruturada em torno da reciprocidade entre partículas olfativas, sistema digestivo humano e consciência.

A experiência imersiva e a performance do corpo humano em contato com tecnologias de virtualidade é assunto da pesquisa apresentada por Carolina Dias de Almeida Berger. Por sua vez, Yara Guasque adota questões da teoria crítica decolonial para tecer uma revisão das poéticas de teleperformance experimentadas no Brasil na virada da década de 1990 para os anos 2000, dentro do projeto Perforum.

A relação da performance com a virtualização espacial é ainda comentada por Michele Augusto, em texto sobre projeto envolvendo fotografia, patrimônio cultural e manipulação manual e digital da imagem. Por sua vez, Raul Dotto Rosa reflete sobre a alteração da experiência sensorial em uma sala expositiva, a partir de uma instalação com elementos de variação visual, sonora e tátil.

O conceito de emergência em sistemas complexos é relacionado ao campo da arte sonora por lanni Luna, em abordagem sobre problemas de autoria e colaboração entre o agenciamento humano e não humano. Por fim, Natasha Marzliak comenta a criação de ambientes virtuais na obra de André Parente, com base na montagem de dispositivos audiovisuais pré- e pós-cinematográficos.

\section{Daniel Hora}

Professor Adjunto do Departamento de Artes Visuais, da Universidade Federal do Espírito Santo e colaborador do Programa de Pós-Graduação em Artes da mesma universidade. Um dos líderes do grupo de pesquisa Fresta: imagens técnicas e dispositivos errantes (Ufes). Faz parte dos grupos de pesquisa Curadoria e Arte Contemporânea (Ufes) e AMBIENTE 33 - Espacialidades, Comunicação, Estética e Tecnologias (UnB). Subcoordenador do projeto de extensão Processos de Criação em Curadoria (Ufes). 